\title{
Can tax evasion tame Leviathan governments?
}

\author{
Frode Brevik • Manfred Gärtner
}

Received: 19 December 2006 / Accepted: 28 January 2008 / Published online: 14 February 2008

(C) Springer Science+Business Media, LLC. 2008

\begin{abstract}
This paper asks to what extent institutional features that facilitate tax evasion may keep Leviathan governments at bay. The specific feature we look at is banking secrecy abroad. The analysis draws on a 16-generation OLG model in which tax rates are determined in a repeated game between voters and a rent-seeking Leviathan government. Key insights are: (1) Effects on any generation alive when change takes place may differ substantially from steady-state effects that accrue for generations yet to be born. (2) There is considerable intergenerational diversity in these effects that is not monotonic as we move from young to old. Combined, these results suggest that the political economy of pertinent institutional change may be quite complex.
\end{abstract}

Keywords Leviathan government · Income tax · Tax evasion · Public spending · Rent seeking

\section{Introduction}

This paper's key question is whether opportunities for tax evasion, such as through bank accounts protected by bank secrecy laws, may lower tax rates and provide an effective check on government spending. The rationale for asking this question is that such effects may improve welfare. This could only be the case, of course, if taxes and government spending levels were excessive in the sense that they are not representative of what individuals actually want. For this to happen, imperfections in the political market or process are required that generate an upward bias in public spending and tax rates.

The claim that banking secrecy does foreign countries a service as well by reducing the effective tax burden of its citizens and keeping their Leviathan governments in check

We thank the editor and two anonymous referees for a host of constructive comments and suggestions. Frode Brevik gratefully acknowledges financial support from the University of St. Gallen's Basic Research Fund.

F. Brevik · M. Gärtner $(\bowtie)$

Institute of Economics, Department of Economics, University of St. Gallen, Bodanstrasse 1, 9000 St. Gallen, Switzerland

e-mail: manfred.gaertner@unisg.ch 
is a familiar part of the political rhetoric of tax haven countries. However, the argument has also been advanced in academic work, as exemplified by Boadway and Keen (1998), who conclude that their results "may point ... to a useful social purpose for tax havens". In their model, in which only capital income is subject to taxation, the government is unable to commit to a tax rate ex ante, before households make their saving decision. Households do anticipate the imbedded incentive to raise taxes after savings decisions have been made. As a result, there is a bias in tax rates that puts them above the socially optimal rate that would obtain if a proper commitment devise existed (see also Fischer 1980; Rogers 1987; Chari et al. 1989). The solution recommended by Boadway and Keen is for the government to precommit to a low level of enforcement of existing tax laws, which they consider easier than precommitment to a lower tax rate, and this way facilitate tax evasion and generate a lower effective tax rate.

This is a strong and potentially provocative result. In order to gauge its robustness and shed additional light on the issue of national and international repercussions of banking secrecy and tax evasion in general, this paper moves beyond the model employed by Boadway and Keen (1998), both in the way the macroeconomy is being modeled, and with respect to the emphasis it allots to the political process.

Regarding the economy, Boadway and Keen (1998) use a representative agent, twoperiod partial equilibrium framework in which income and the capital stock are exogenous. Our analysis features an infinite horizon general equilibrium model with heterogeneous households. This permits a more comprehensive analysis of macroeconomic steady-state effects, a first look at intergenerational conflict, and, due to the inclusion of 16 generations, the derivation of quite realistic and refined medium-run dynamics.

The political process does not play an explicit role in the Boadway and Keen (1998) paper. Implicitly, though, the fact that the government and society share identical preferences may be attributed to perfect competition in the political arena. As stated above, a Leviathan effect obtains because socially optimal low tax rates are not time consistent. This causes an upward bias in tax rates that not only voters but the government as well would like to get rid of. Hence, there is no conflict of interest between the government and the electorate, and anything that weakens the mechanisms provoking the tax bias helps cutting Leviathan down to size. Such conflict is at the very core of our model, however. Mainly as a driving force behind the game the rent-seeking government (that benefits from high tax rates) plays with the voting public (who tries to prevent costly lame-duck behavior on the part of the government). But also because institutional change bears differently on generations alive and generations yet to be born, and may even have quite contrasting effects on different generations currently alive. All this renders the issue of how to reduce the Leviathan effect a lot more complex and interesting.

In order to achieve maximum leverage for any results that might obtain from this paper's analysis, we model Leviathan government in its most extreme form, postulating that the public wants no public spending at all, and all public spending is the sole result of rentseeking behavior by politicians. The specific description of the political process we employ is the electoral control model proposed by Ferejohn (1986) used extensively in the pertinent literature. This game-theoretic specification of how voters and the government interact is combined with a 16-generation overlapping generations model in which generations are born one election period apart to match the rhythm in which political decisions are being made. The added benefit from equipping the economy with a relatively large set of heterogeneous agents spaced apart by relatively short periods only is that it generates rather detailed dynamics, provides insights into intergenerational diversity and the political prospects for institutional change, and may serve as a point of departure for future work that looks at political decision processes explicitly and more closely. 
The idea that governments should be thought of as self-serving Leviathans rather than as maximisers of social welfare has a long history in political philosophy. ${ }^{1}$ Explanations of why the size of the government sector may be excessive abound in the public choice literature, ranging from Tullock's (1967) emphasis on rent-seeking activities via Niskanen's (1971) focus on the role of budget-maximizing behavior to Brennan and Buchanan's (1980) hypothesis that, in the absence of constitutional constraints on the power of politicians, lack of competition among decentralized government units may be the culprit. ${ }^{2}$ Our topic is also related to the literature on tax competition and information exchange, but this literature usually maintains that each country's government seeks to maximize the utility of its inhabitants. Moreover, our concern is not to analyze the strategic interaction of different countries (see Bacchetta and Espinosa 1995, 2000; Kollintzas et al. 2000; Huizinga and Nielsen 2003; Marchand et al. 2003; Eggert and Kolmar 2004), but to investigate how changes between different regimes of information exchange impact different groups.

Section 2 develops our overlapping generations model with Leviathan government, gives some analytical results, and discusses steady states as they obtain with and without tax evasion opportunities. Section 3 looks at dynamics. For that purpose, we simulate a calibrated numerical version and track both the response of aggregate variables and the behavior of individual generations to institutional change toward and away from arrangements with banking secrecy. Section 4 sums up and provides an outlook on possible future refinements and extensions.

\section{An OLG model with Leviathan government}

\subsection{The economy}

We use a small open economy overlapping generations (OLG) model featuring 16 generations. The reason why we are looking at more than the two generations often employed in OLG models is that this permits us to look at transition dynamics and generational diversity in a realistic fashion. Sixteen generations seem appropriate for our purposes, as they insinuate a period length of some four years, the length of an election period, which plays a key role in our model. A new generation is born at the beginning of a new election term. Each generation supplies a fixed labor input which is normalized to 1 during the first 12 periods of its lifetime. ${ }^{3}$ After that it retires and lives solely from its savings plus interest. Individuals are born without wealth and leave no bequests. For ease of notation we identify generations by noting how many periods they have left to live after the current period. Accordingly, the oldest generation is generation 0 , while generation 15 is the youngest. Net output per worker at time $t, y_{t}$, is generated by a Cobb-Douglas production function

$$
y_{t}=k_{t}^{\alpha}-\delta k_{t},
$$

\footnotetext{
${ }^{1}$ Typical citations are taken from the writings of Thomas Hobbes, who first likened the government to the biblical monster, James Stuart Mill and Jean-Jacques Rousseau.

${ }^{2}$ The question of how to limit Leviathan also has a long tradition in the public choice literature. The wide range of remedies suggested, which reflect the multitude of potential causes of an excessive size and scope of government, are comprehensively surveyed in Racheter and Wagner (1999).

${ }^{3}$ Fixing each generations supply of labor is needed to keep the model tractable and is standard in OLG models. Ruling out this specific source of legal tax avoidance at the same time ensures that no Laffer-type relation between the tax rate and the tax base exists. We are confident that the qualitative properties of the results presented in papers are robust to such an extension as long as we operate on the rising segment of the Laffer curve. Things may look different, though, if we move beyond.
} 
where $k_{t}$ is the capital stock per worker, $\alpha$ is capital's share of output, and $\delta$ denotes the depreciation rate. Both capital and labor markets are perfectly competitive, so that both production factors are reimbursed at their marginal productivity. Accordingly,

$$
r_{t}=\alpha k_{t}^{\alpha-1}-\delta k_{t}, \quad w_{t}=(1-\alpha) k_{t}^{\alpha},
$$

where $r_{t}$ is the real period (not annualized) interest rate and $w_{t}$ is the wage rate. Declared wage and interest income is taxed at a flat period rate $\tau_{t}$. Wage income is always fully declared, while, depending on the judicial setting, households may or may not use means such as banking secrecy to evade taxes on interest income. We assume that tax evasion generates a period cost of $\frac{1}{2} \zeta f^{2}$ per unit of assets hidden in secret bank accounts, where $f$ is the fraction of assets the household hides from the authorities. ${ }^{4}$ This implies an optimal tax evasion rate of

$$
f_{t}=\frac{r_{t} \tau_{t}}{\zeta}
$$

The resulting after-tax interest and wage rates are given by

$$
\begin{aligned}
r_{\text {net }, t} & =\left(\left(1-\tau_{t}\right)\left(1-f_{t}\right)+f_{t}\right) r_{t}-\frac{1}{2} \zeta f_{t}^{2}, \\
w_{\text {net }, t} & =\left(1-\tau_{t}\right) w_{t} .
\end{aligned}
$$

Each country's size is negligible compared to the world economy. We assume perfect capital markets and that capital income is taxed according to residence. International interest rate parity requires that the per worker capital stock is level across countries, so unilateral policy choices will not have an impact on output or wages.

In general equilibrium models with government, households typically derive utility from private consumption and their government's provision of public goods. The lifetime utility of the representative member of generation $n$ is given by

$$
V_{n}=\sum_{j=0}^{n} \beta^{j}\left(\log c_{n-j, t+j}+\psi \log g_{t+j}\right),
$$

where $c_{n-j, t+j}$ is period $t+j$ consumption of generation $n-j, g_{t+j}$ the level of public good provision per capita in the same period, $\psi$ the weight of public goods in households' utility, and $\beta_{h}$ households' subjective time-discount factor. An extreme, pure Leviathan model obtains if we let $\psi$ equal zero. Then government spending generates no utility for households at all. We denote the net wealth (the sum of the market value of assets held and future net wage earnings discounted at the after tax interest rate) of a representative individual of generation $n$ by $v_{n}$. Since the youngest generation starts out without any assets, its net wealth, $v_{15, t}$ is given solely by the discounted value of future net salaries

$$
v_{15, t}=\sum_{j=0}^{12} \frac{\left(1-\tau_{t+j}\right) w_{\text {net }, t+j}}{\prod_{i=1}^{j}\left(1+r_{\mathrm{net}, t+i}\right)} .
$$

\footnotetext{
${ }^{4}$ The costs of tax evasion come in many forms. They involve the risk of punishment for evading taxes in the spirit of Allingham and Sandmo (1972), psychological costs of deviating from personal norms (Schnellenbach 2006), losses resulting from the need to conceal the buying power from this kind of illegal income by putting it to inefficient use, and, probably most directly, withholding taxes levied by the country that is offering secret bank accounts.
} 
As we show in Appendix A, the optimal consumption of generation $n$ individuals is given by

$$
c_{n, t}=\frac{1-\beta}{1-\beta^{n+1}} v_{n, t} .
$$

The fraction of wealth that any generation consumes during a given time period, $(1-\beta)$ / $\left(1-\beta^{n+1}\right)$, decreases with the number of periods it has left to live and is higher the more households discount future consumption $(\beta)$. In the last period the generation consumes all its remaining wealth, while for young generations, the fraction consumed approaches $(1-\beta)$. The generation's wealth next period will be given by the part of current wealth not consumed plus the interest income they receive on this, or

$$
v_{n-1, t+1}=\left(1+r_{\text {net }, t+1}\right) \frac{\beta-\beta^{n+1}}{1-\beta^{n+1}} v_{n, t} .
$$

Net interest rates, as determinants of net wealth, depend on income tax rates. These are determined in a game between voters and the government which we now describe and analyze.

\subsection{The game between voters and the government}

In order to provide an explanation of tax rates with Leviathan-government flavor, this section augments the OLG model described above with a version of Ferejohn's (1986) electoral control model. This model has become a staple in political macroeconomics with a wide range of applications (e.g., Rogoff 1990 or Persson et al. 2000). It assumes that politicians are pure rentseekers. When in power, they have the discretion to tax net income at any rate they deem appropriate. But the constitution prevents them from the outright expropriation of private assets. ${ }^{5}$

Politicians maximize income. When in office, income comes in two forms: First, they receive an explicit salary which they cannot influence. For the sake of parsimony, we assume that it equals the salary they could earn in private-sector positions. Second, politicians can gain additional income by pursuing activities which favor special consumer or producer groups. We are interested in this second type of income, generated through rent-seeking behavior. These rents may accrue openly and legally, say as payments from recipients of government contracts in the form of campaign contributions, promises of future employment, or lecture fees (Stigler 1971; Barro 1973). In countries with weak legal rules and enforcement, in particular, such income may also arrive through concealed, illegal channels, such as bribes and other forms of corruption. Following Barro (1973) we let government rent be generated through factor overpayment in public procurement. It is thus proportional to (certain parts of) government spending.

When determining government spending, we assume that the government budget must balance on a period-by-period basis, which, in our context, means over an election term. For

\footnotetext{
${ }^{5}$ Of course, an appropriately designed constitution may restrict overtaxation as well. Brennan and Buchanan (1980) discuss this issue in considerable detail. Our approach is a positive one, proposing a constitutional design with the main features we observe in real life, even if these are suboptimal by the standards of Brennan and Buchanan, for whatever reason. In our reading the majority of constitutions in industrial countries do prohibit outright expropriation while leaving some leeway for government spending and tax policies. This leads us to the question whether opening venues for tax evasion may be a second-best optimum.
} 
a tax base $b_{t}$ and a tax rate $\tau_{t}$, government spending per capita is thus given by

$$
g_{t}=\tau_{t} b_{t}
$$

Further, assume that some part of government spending is not discretionary, but mandated by a country's legal commitments (schools, public hospitals, etc.), by international treaties or standards suggested by supranational institutions. Let this part of government spending be fixed at $\bar{g}$ and assume that such non-discretionary spending does not generate rent for the government. So rents are linear in that part of government spending that exceeds the legal minimum. The period $t$ rent $\xi_{t}$ generated by such discretionary spending is thus given by

$$
\xi_{t}=\xi\left(g_{t}-\bar{g}\right)=\xi\left(\tau_{t} b_{t}-\bar{g}\right) .
$$

Within a given period (or term in office), the government would maximize its rent by driving up the tax rate to $100 \%$. This short-run incentive is counterbalanced by its desire to get reelected and thus be able to collect rents in the future as well. Voters are aware of this tradeoff and adopt a simple performance-oriented (retrospective) voting rule: If the tax rate $\tau_{t}$ set by the government does not exceed a threshold $\bar{\tau}_{t}$, the current government gets reelected. Otherwise it receives zero votes and a new government is elected from an infinite pool of other parties. Once out of office, a former government never returns to power. There are no mechanisms by which a government can credibly pre-commit to a policy unless it is ex-post rational. The timing of this simple game is visualized by the sequence of events given in Fig. 1.

Given the voting rule mentioned above, the reigning rent-seeking government has two options: First, to maximize the current period rent by setting $\tau=100 \%$, and accept being voted out of office. Second, to settle for a lower tax rate $\bar{\tau}_{t}$ that gets it reelected. Choosing a tax rate below $\bar{\tau}_{t}$ will never be optimal, of course, because a marginal increase in the tax rate would increase revenues without impeding chances for reelection. Also, no rational government will ever pick a tax rate in the range between $\bar{\tau}_{t}$ and $100 \%$, because a tax rate of $100 \%$ provides higher rents and identical reelection prospects.

The challenge for the electorate is to set incentives for the government in such a manner that it always opts for a tax rate of $\bar{\tau}_{t}$ and never for one of $100 \%$. The criterion for this can be found by recursion. Given that it will be optimal for the government to choose $\tau_{t+j}=\bar{\tau}_{t+j}$ in all future periods $t+j$ and that its discount rate is $\beta_{g}$, this choice is also optimal at time $t$ if the maximal current period rent does not exceed the present value of the stream of future rents when in power. Formally,

$$
\xi\left(b_{t}-\bar{g}\right) \leq \sum_{j=0}^{\infty} \beta_{g}^{j} \xi\left(\bar{\tau}_{t+j} b_{t+j}-\bar{g}\right) .
$$

Fig. 1 The game between voters and the government: sequence of events

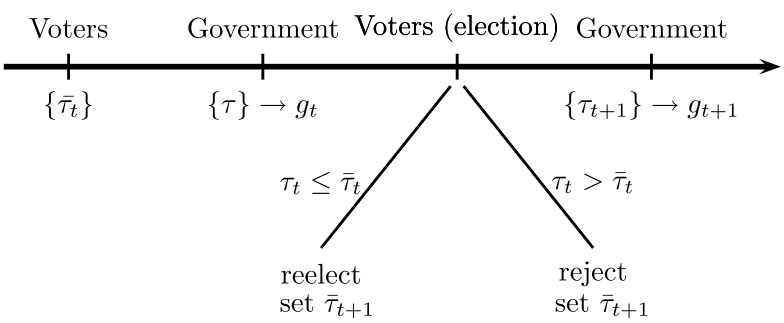


From the perspective of the electorate, this is the incentive compatibility constraint. The optimal tax rate $\bar{\tau}_{t}$ is the one that makes (7) hold with equality. Rearranging (7) gives

$$
\bar{\tau}_{t}=1-\frac{1}{b_{t}} \sum_{j=1}^{\infty} \beta_{g}^{j} \bar{\tau}_{t+j} b_{t+j}+\frac{\beta_{g}}{1-\beta_{g}} \frac{\bar{g}}{b_{t}} .
$$

Equation (8) provides some insights at to why $\bar{\tau}$ might fluctuate over time. The second term will be larger (in an absolute sense), the smaller the current tax base is relative to its long-run value. This reflects the fact that incumbents have more to gain from staying in office when the tax base is rising. As we can see from the last term, a growing tax base leads to lower tax rates, as the fraction of revenues necessary to cover non-discretionary spendings decreases.

Our political-economic OLG model can be used to identify government behavior and the state of the economy under different institutional settings. We look at two such settings. The first one does not provide windows of opportunity for tax evasion. Here $f$, the fraction of wealth concealed from tax authorities, equals zero. And the other setting is one in which such opportunity presents itself, as would be the case when foreign countries offer secret bank accounts. Here $f$ is optimally chosen by households given the cost function for tax evasion. We start by briefly discussing steady states under the two institutional settings. We then proceed to look at the dynamic responses triggered when one institutional setting is dropped in favor of the other.

\subsection{Steady states with and without banking secrecy}

Steady-state solutions are obtained by removing all time indices. Doing this in (8) yields the steady-state tax rate

$$
\bar{\tau}=\left(1-\beta_{g}\right)+\beta_{g} \frac{\bar{g}}{b} .
$$

Without banking secrecy (or with banking secrecy and information exchange between countries), the tax base equals GDP. The larger the fraction $f$ of interest income hidden from the tax man, the lower is the tax base relative to GDP, and the higher is the tax rate set by the government in equilibrium. Hence, part of the revenue lost due to tax evasion is recaptured through higher official tax rates.

The labor supply is fixed in our setup. So the effect of tax evasion on GDP, on the gross wage rate, and on the gross interest rate will be determined by its effect on the capital stock. ${ }^{6}$ In the new steady state with tax evasion, taxes are shifted from capital income to labor. This is because the tax rate effectively paid on wage income equals the official tax rate, while the tax rate effectively paid on interest income, part of which evades being taxed, is below the official tax rate. This raises effective post-tax interest rates, which translates into higher savings rates.

Since subsequent sections report dynamic effects relative to steady states, it is useful to note that while aggregates do not change in the steady state, intra-generational dynamics occur nevertheless. Since the discussion of dynamic responses to institutional change in Sect. 3 requires a calibrated version of our model, we also provide quantitative steady-state patterns here for reference. To this end, the model is calibrated as follows: The production

\footnotetext{
${ }^{6}$ We noted above that each individual country is small, so that its repercussions on the global economy are negligible. When all individual countries respond in the same way, however, this does affect the global capital stock.
} 
function parameter $\alpha$ is set to 0.3 . Capital depreciates by $40 \%$ each period (12\% per year). Non-discretionary government spending $(\bar{g})$ is set to $45 \%$ of the equilibrium GDP under banking secrecy. The government discount factor is set to $10 / 11$, which gives a steady-state tax rate with banking secrecy of $50 \%$. The households' discount factor is calibrated to match an annual interest rate of 0.04 with banking secrecy; this is achieved at $\beta_{h}=0.9120$. The parameter $\zeta$ in the cost function is calibrated to generate a tax evasion fraction of 0.1 ; this is achieved at a $\zeta$ of 0.85. The solution algorithms we use are described in Appendix B.

The solid line in Fig. 2 has two interpretations. The first is timeless, since it indicates the consumption levels of the sixteen generations alive at an arbitrary point in time, after the economy has settled into a steady-state without banking secrecy. The youngest generation is positioned on the left and the oldest on the right. This line may also be given a dynamic interpretation. Since households move from left to right as they get older, the line also shows the lifetime consumption profile of a representative household. The fact that consumption falls during a household's life implies that our calibration generates a steady-state real interest rate that falls short of the time discount rate. The dashed line provides the same kind of information for a steady state with banking secrecy. The fact that the pattern has become flatter indicates that the effective post-tax real interest rate has increased. It still remains below the time discount rate, though, since households continue to favor early consumption.

For those generations who work, the higher official tax rates mean lower net wage rates, but the effect of the higher effective interest rate on the savings rate turns out to be strong enough to compensate for this effect for all generations. The upshot is a higher capital stock with secret bank accounts. Through the production function, a higher capital stock also drives up GDP and the wage rate, but has a dampening effect on the interest rate.

\section{Dynamic responses to institutional change}

Lifetime in OLG models is finite, and many, if not all, generations currently alive may not live to enjoy whatever promises a distant new steady state may bear. When discussing the welfare implications of institutional change, therefore, and even more so when evaluating prospects for its political implementation, we need to look at the model's dynamics. For this purpose, the current section analyzes the transition paths to (from) an institutional design

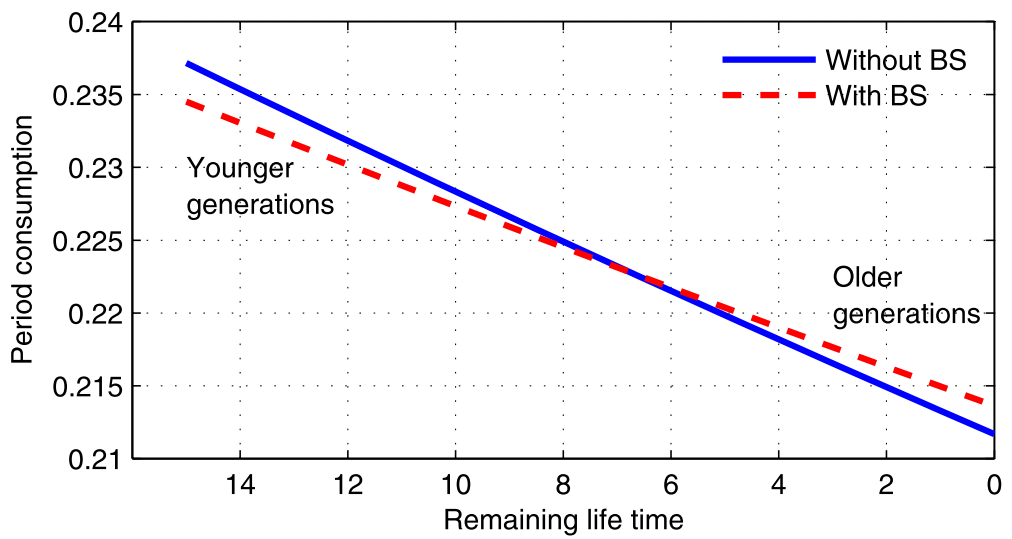

Fig. 2 Steady state consumption profiles 
with banking secrecy from (to) one without (or with) information exchange, in a numerical version of our model.

\subsection{Introducing banking secrecy}

\subsubsection{Aggregate dynamics}

Figure 3 shows how tax rates, the tax base, the capital stock and consumption respond to the establishment of secret bank accounts. All time paths are relative to the steady-state patterns that obtain without banking secrecy. In period -1 the economy is still in a steady state without any opportunities for tax evasion. In period 0 the government and households learn that from next period on secret bank accounts will be available. Households respond to this by keeping a fraction $f$ of their assets in such accounts in period 1 and after. For now we assume that this reallocation takes time, so that households respond to what they learned with a lag of one period.

The upper-left panel shows that the tax rate spikes in the announcement period, period 0 . It drops in period 1, and then recedes slowly toward its new equilibrium value, which is higher than the old one. This observed initial spike is due to the drop in politicians' rent anticipated to follow the future opening of channels for tax evasion. In period 0 , households have not had the opportunity yet to react to this opening. The tax base, the sum of wage and interest income, therefore, is still the same as in the previous steady state. In this old steady state, voters disciplined the government by letting it tax just enough to render it indifferent between the tax rate that is moderate enough to get the government reelected at all future elections, and a tax rate of $100 \%$, followed by being ousted from office at the next election. Politicians know that tax evasion made possible by secret bank accounts will eat into the tax base in the near future. So, unless voters adjust the tax rate at which they reelect the government $\left(\bar{\tau}_{0}\right)$, the incentive compatibility constraint of inequality (7) will be violated.

The initial spike also impedes wealth accumulation and reverberates in the following periods in the form of an initially lower capital stock (lower-left panel). This adds to the drop in the tax base that follows households shift of assets abroad (upper-right panel). As we move ahead in time, the capital stock not only rebounds, but soars above its initial level thanks to the lower effective tax rate that banking secrecy implies. This slight rebound of the tax base is perfectly foreseen, and, as we know from the discussion of (8), will lead to a further decrease in tax rates as a smaller fraction of revenues needs to be set aside to cover non-discretionary spending.

Aggregate consumption (lower-right panel) is initially also dented by the initial tax hike, but also by a temporal shift in households' consumption profiles (see below). After some periods below the old level, it recovers as the effect of the consumption shifts are smoothed out, the tax burden eases, and aggregate wealth reaches its new, higher long-run level.

The key lesson to be taken from the figure is how the equilibrium tax rate tracks future shifts in the tax base. If, as initially, the current tax base is higher than that of the next few periods, incentive compatibility requires $\bar{\tau}$ to be increased. If, as from period 2 on, the tax base is on an ascending trajectory, politicians would be willing to accept temporarily lower tax rates, but this effect will be muted or dominated by a decrease in the fraction of revenues needed to cover basic government services over time.

\subsubsection{Generational dynamics}

Aggregate dynamics, as given in Fig. 3, provide an incomplete picture in an OLG model. First, because different generations alive deviate from the average or benefit from the average in different ways. And second, because even if all generations' consumption would 
exactly follow the path of aggregate consumption shown in Fig. 3, each generation would be able to move along this path for a different length of time. Thus the present value of consumption dynamics triggered by the introduction of banking secrecy abroad would be different for each generation. This section, therefore, looks behind the aggregates shown in Fig. 3 and discusses how each generation's consumption is being affected.

The lower panel of Fig. 4 shows the present values of the effect on consumption ordered by generation. ${ }^{7}$ Interestingly, the effect is not monotonic in the sense that it changes in one direction as we move from younger toward older generations. Both the oldest generation and the eleven youngest generations suffer from the introduction of banking secrecy. The four other generations do welcome banking secrecy. To understand this pattern, it helps to note that those who benefit are the generations who will still be alive when banking secrecy eventually is implemented, which happens in period 1 , and will then have to make a liv-
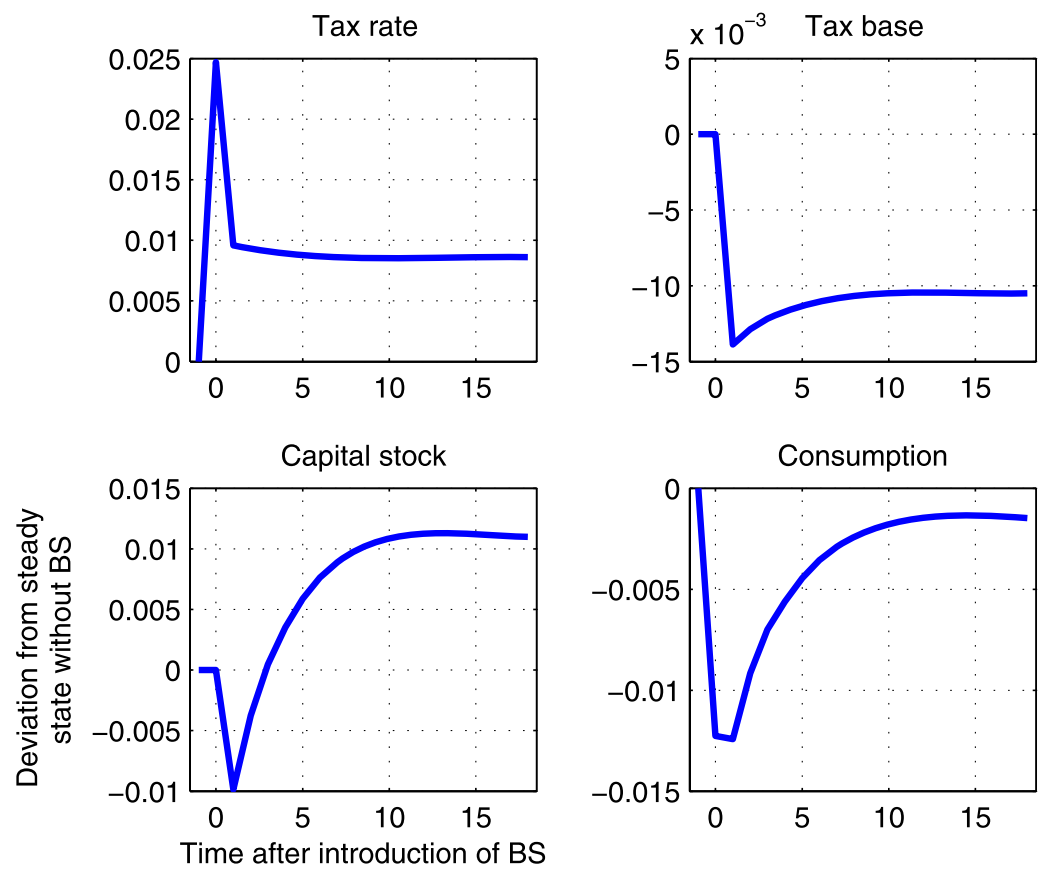

Fig. 3 Introducing banking secrecy: the aggregate perspective

${ }^{7}$ For each generation, this is computed as the percentage shift in the consumption path from the previous
steady state that would make it indifferent between remaining in the old regime and switching to the regime
with secret bank accounts. Denoting the hypothetical consumption that would have accrued in the old steady state by $\hat{c}$ we find the equivalent overall consumption change by solving

$$
\sum_{j=0}^{n} \beta_{h}^{j} \log c_{j}=\sum_{j=0}^{n} \beta_{h}^{j} \log \left(\hat{c_{j}}\left(1+\Delta_{n}\right)\right)
$$

for $\Delta_{n}$. This yields

$$
\Delta_{n}=\frac{1-\beta_{h}}{1-\beta_{h}^{n+1}} \sum_{j=0}^{n} \beta_{h}^{j}\left(\log c_{j}-\log \hat{c}_{j}\right)
$$


ing out of interest income and accumulated wealth alone. Those who suffer are the other generations. The generation shown on the far left lives during the period when the implementation of banking secrecy is announced (but not yet implemented) and the government responds by raising tax rates. This lowers their disposable income and consumption, which remains the only effect they experience before they pass away. The eleven youngest generations will all still have to work under banking secrecy and pay higher taxes and save out of lower disposable incomes during that time. This apparently dominates all positive effects banking secrecy may have on their consumption via a build-up of the capital stock and lower effective tax rates during their years of retirement.

To provide an even more detailed picture, the upper panel shows consumption paths for each individual generation. Note that these are deviations from the no-banking-secrecy steady-state consumption paths shown in Fig. 4. So while paths in the top panel of Fig. 3 are predominantly ascending, the increase is relative to the descending steady-state paths of Fig. 4. Since these steady-state paths descend more steeply, this dominates the steady-state paths with banking secrecy still. So consumption falls during the remaining lifetime for most generations, but less so in a scenario without banking secrecy.

Let us first look at the uppermost path which is actually four paths stacked on top of one another. Paths have been deliberately displaced slightly to make it even more apparent that we are looking at four paths rather than one. The four paths are for the four generations already in retirement when the future implementation of banking secrecy is being announced. These generations are all being affected in the same way each period, but for a different number of periods.

All retired generations live by consuming wealth accumulated during their working lives, and from the interest income this wealth still generates. The oldest generation unambiguously loses from the introduction of secret bank accounts. The reason is that its disposable income is affected full force by the spike in the tax rate that hits their consumption during their only period left to live. The three other generations also in retirement already suffer from this blow the same way. However, they also benefit during subsequent periods from the actual introduction of secret bank accounts. The combination of income tax rates at home coming down again and the possibility of actually moving part of their wealth abroad lets them enjoy lower effective tax rates for the remainder of their lives. As this drives effective post-tax interest rates below their steady-state value, meaning that today's consumption is reduced in favor of more consumption tomorrow. This creates ascending consumption paths of retired generations who live to see secret bank accounts implemented.

Intertemporal substitution of current consumption in favor of later consumption also is the key mechanism behind the upward-sloping consumption paths of those generations who still hold jobs in period 0. Two features need explanation there, however. First, why is the announcement-related drop in period 0 larger the longer the remaining work life? Second, why does consumption for generations still young continue to fall in period 1, while it is already rising for the older working generations?

In answering the first question we note that because wage income is taxed at the official tax rate, which increases when the introduction of bank secrecy is being announced, banking secrecy triggers a shift of taxation from capital income to wage income. This hurts those generations most who are still early in their careers and adds to the reduction in current consumption that is already being caused by the anticipated rise in after-tax interest rates.

Regarding the second question, those generations with the longest working lives ahead have not accumulated any wealth worth talking about yet. Their disposable incomes will be affected strongly by the drop in the capital stock in period 1 and by the detrimental effect this has on their labor income. The older a generation is and the larger its accumulated wealth, 

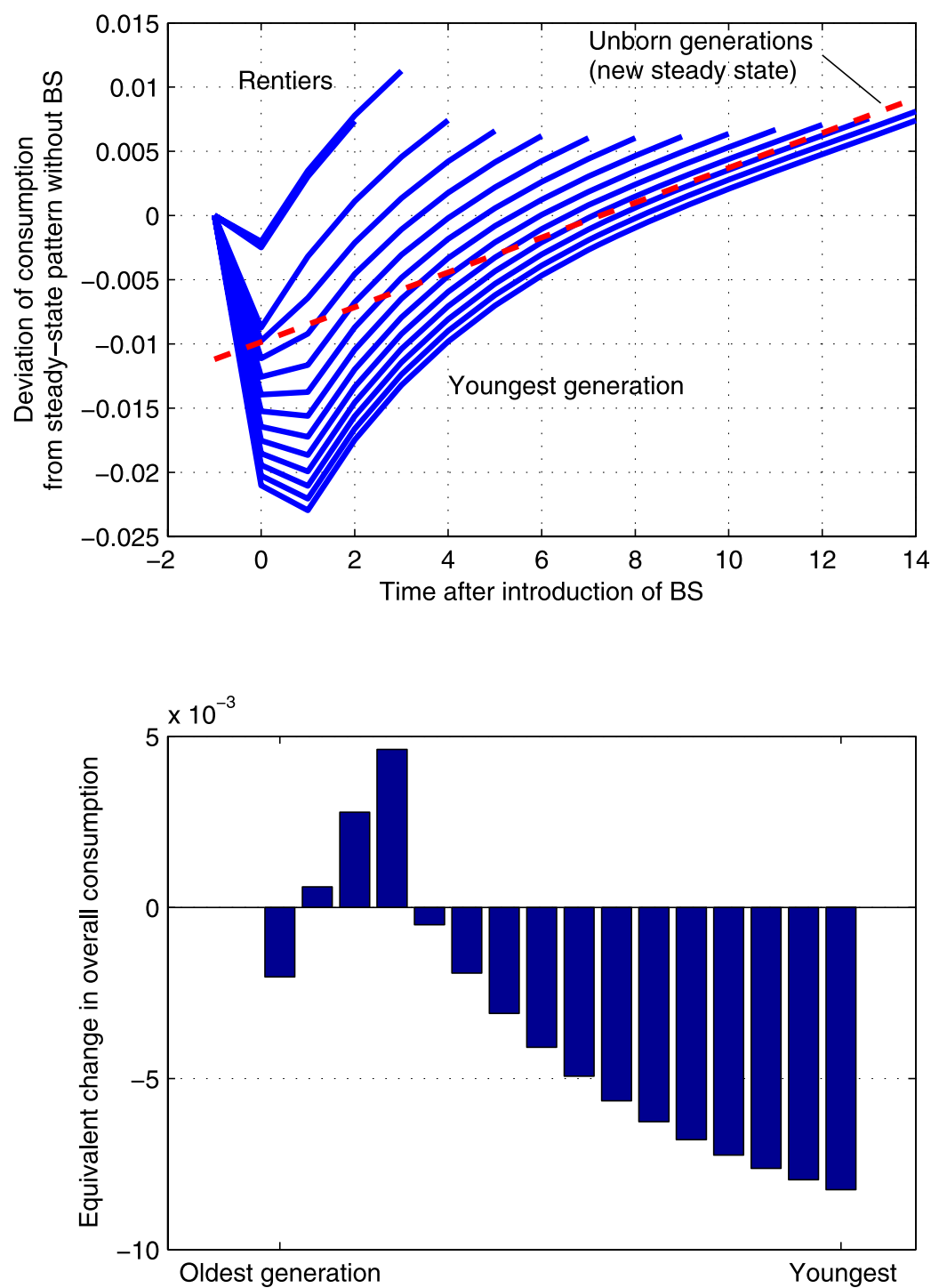

Fig. 4 Introducing banking secrecy: the generational perspective

the more likely this negative effect on wages will be offset by the new opportunity to move financial wealth abroad and receive a tax-free return.

\subsection{Abolishing banking secrecy}

Institutional change in the opposite direction, toward an abolition of banking secrecy, simply mirrors the patterns described above, when it is being implemented in the same fashion. In order not to become repetitive and broaden our insights while looking at this case, we now assume that banking secrecy is discarded unexpectedly, without previous announcement. 
Again, we start by looking at the dynamic response of aggregate variables, shown in Fig. 5. With the regime change, happening in period 0 , the tax base jumps (northeast panel), because those parts of wealth which before were hidden from the tax man are now subject to taxation. Reflecting this jump in the tax base, the tax rate drops (northwest panel). The dominant factor in this drop is the lower fraction of revenues needed to cover non-discretionary spendings. There is not much time variation in the subsequent movements of the tax base or the tax rate, since both variables jump into the neighborhood of their new steady states instantly. Whatever movement happens after is not very significant in quantitative terms and reflects the effect of the falling capital stock on output (lower-left panel). The response of consumption is interesting (lower-right panel). It jumps upward when banking secrecy is abolished, reflecting the drop in the tax rate, which has not affected the capital stock yet, and intertemporal substitution toward earlier periods for all generations.

This shift in consumption patterns is clearly recognizable in the upper panel of Fig. 6, which looks behind aggregates at individual generations. All generations, except the five oldest, have higher consumption in the periods immediately following the abolition of banking secrecy, but lower consumption toward the end of their lifecycles. As with the introduction of banking secrecy, the tilting of the consumption profiles is mainly due to changes in the effective interest rate. Without banking secrecy it is lower because all interest income is subject to the domestic tax rate.

The lower panel shows the winners and losers of the postulated institutional change. The effects mirror - but not perfectly so-what we saw happening after the introduction of banking secrecy. Since we assume that banking secrecy is dropped unexpectedly, the oldest generation also loses with this policy shift. Apart from that, the pattern is more or less the opposite of what happened after the introduction of banking secrecy. Retired generations, as well
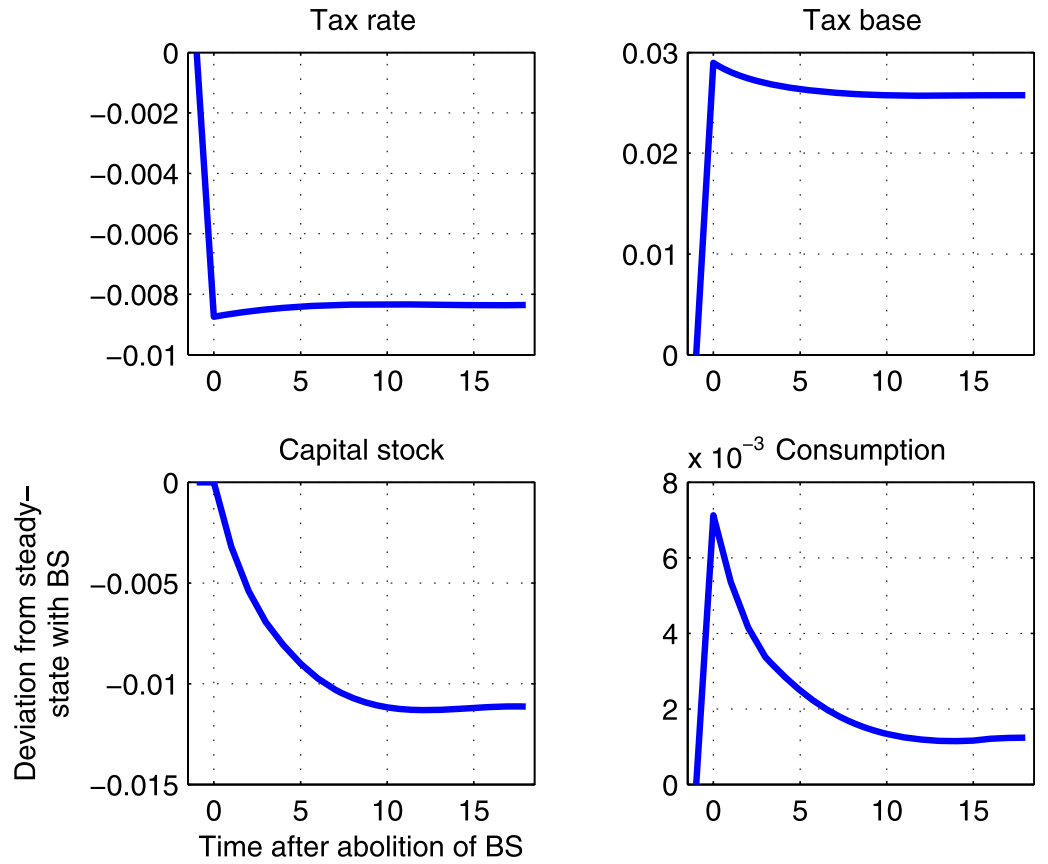

Fig. 5 Abolishing banking secrecy: the aggregate perspective 

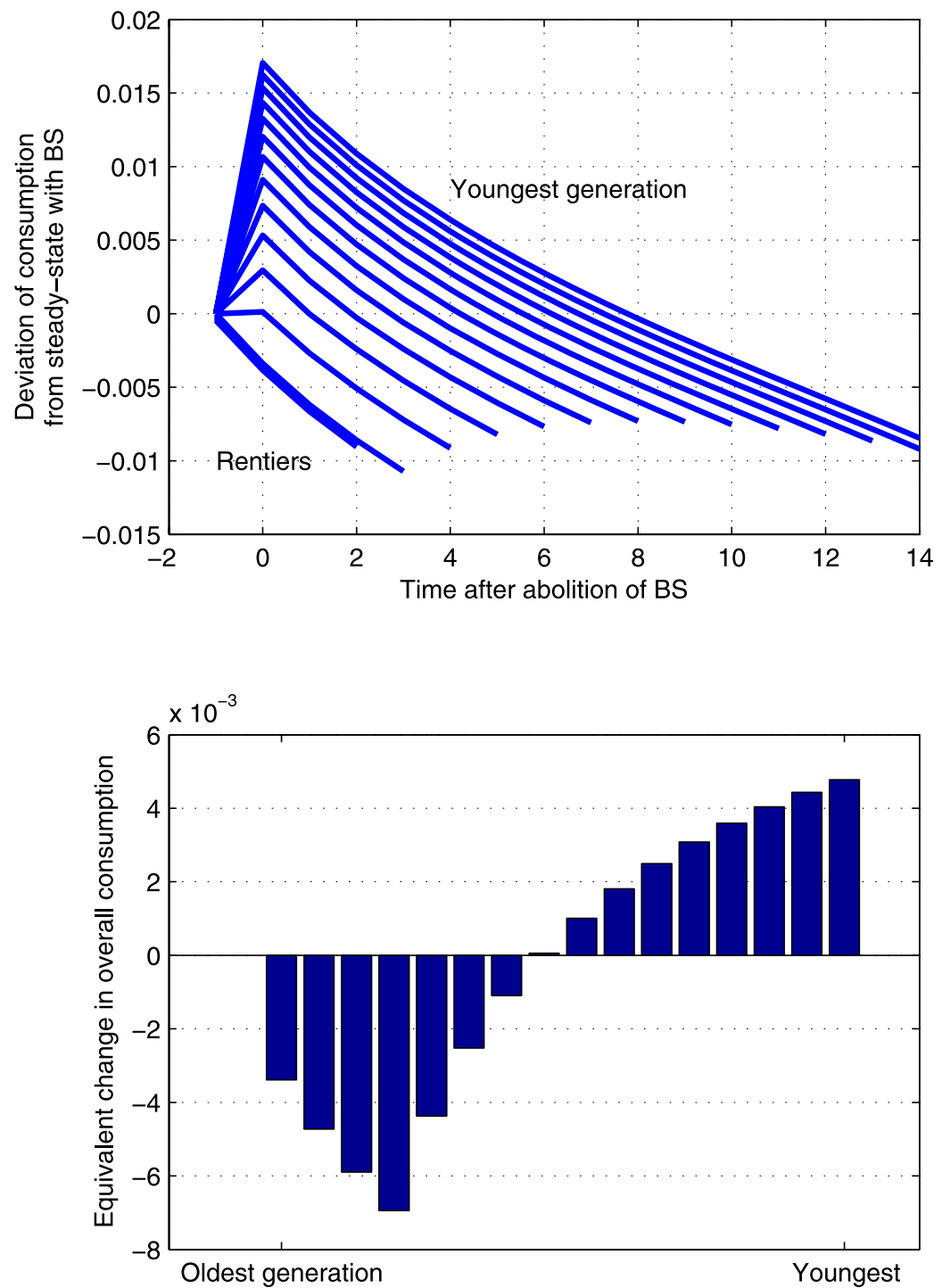

Fig. 6 Abolishing banking secrecy: the generational perspective

as those in the late periods of their working lives lose because they derive all or most of their income from their financial assets. The new official tax rate is lower without banking secrecy and this benefits the younger generations who have many working periods ahead of them.

\section{Summary and outlook}

The main question asked in this paper was to what extent institutional features that facilitate tax evasion may keep Leviathan governments at bay. The specific feature we looked at was 
banking secrecy abroad, but most results would seem to apply to other institutional features facilitating tax evasion as well. The answer to the main question depends on how one defines Leviathan, or the government.

When taking income tax rates as a measure of government power abuse, tax evasion feeds Leviathan. Even with an extreme specification of Leviathan governments, in which all public spending is forced upon households and does not even enter their utility function, tax rates go up. Since this is accompanied by a dramatically shrinking tax base, however, due to a substantial part of income now being concealed from the tax authorities, taxes per capita do indeed fall. Households benefit from this through higher consumption that eventually moves beyond previous levels, made possible by a growing capital stock and lower effective tax rates.

These are all steady-state effects, however, and some of them take substantial time to materialize, a highly relevant aspect when lifetime is finite. Looking into this, our analysis has shown that the effects of institutional change in terms of introducing banking secrecy, or removing it, are quite complex. Not only may patterns differ substantially between generations, but present values of changes in consumption also depend crucially on generational status, which defines expected remaining lifetime, on the speed at which institutional change is conducted and on the element of surprise it contains. The immediate effect of announcing the introduction of banking secrecy is a drop in consumption. The drop is more pronounced the longer is the remaining lifetime of a household. For many this drop is followed by a further fall in consumption when banking secrecy actually is implemented, and households may never recover from these losses during later stages of their lives. When the introduction of banking secrecy is pre-announced, the net effect on a majority of households is negative. When the introduction catches the economy by surprise, a majority may benefit.

Future work may extend our analysis in a number of directions. For one thing, our definition of Leviathan may be softened to a less extreme version. As the model stands now, cutbacks in government spending do not matter to households, as public consumption does not generate utility. Figures 7 and 8 offer a glimpse at how this may bear on results by showing how government spending per capita responds to an announced and to a surprise removal of banking secrecy. Dynamic and present-value effects on consumption, already shown in Sects. 3.1 and 3.2, are also included for easy reference.

What catches the eye is the downward spike in government spending when next period's abolishment of banking secrecy is announced (Fig. 7). This reflects the downward spike in the tax rate (the opposite of what we have seen in Fig. 2), and is so severe that subsequent higher levels of government spending never make up for it during the lifetimes of all generations currently alive. This spike is absent when there is no previous announcement (Fig. 8). Therefore, the effect on all generations is positive. What is interesting is that there seems to be a tradeoff: A pre-announced abolishment of banking secrecy benefits most households from the perspective of consumption, but hurts public consumption for all. Abolishment in a surprise move hurts a majority of households from the perspective of consumption, but improves public consumption for all. We need to emphasize, however, that the government's spending patterns have been computed in a model in which they do not yield utility. So households do not care about the patterns shown in Figs. 7 and 8. Making public consumption a determinant of household utility would also affect the game between households and the government and bear on the paths of other variables as well.

Beyond measures of aggregate or generational welfare, any evaluation of prospects for political change, or persistence, needs to dig deeper into the political process. Thus, future work may make the option for institutional change part of the political game, and consider the interaction between the government and the median-voter generation in an effort to model the political part of the model more realistically. 

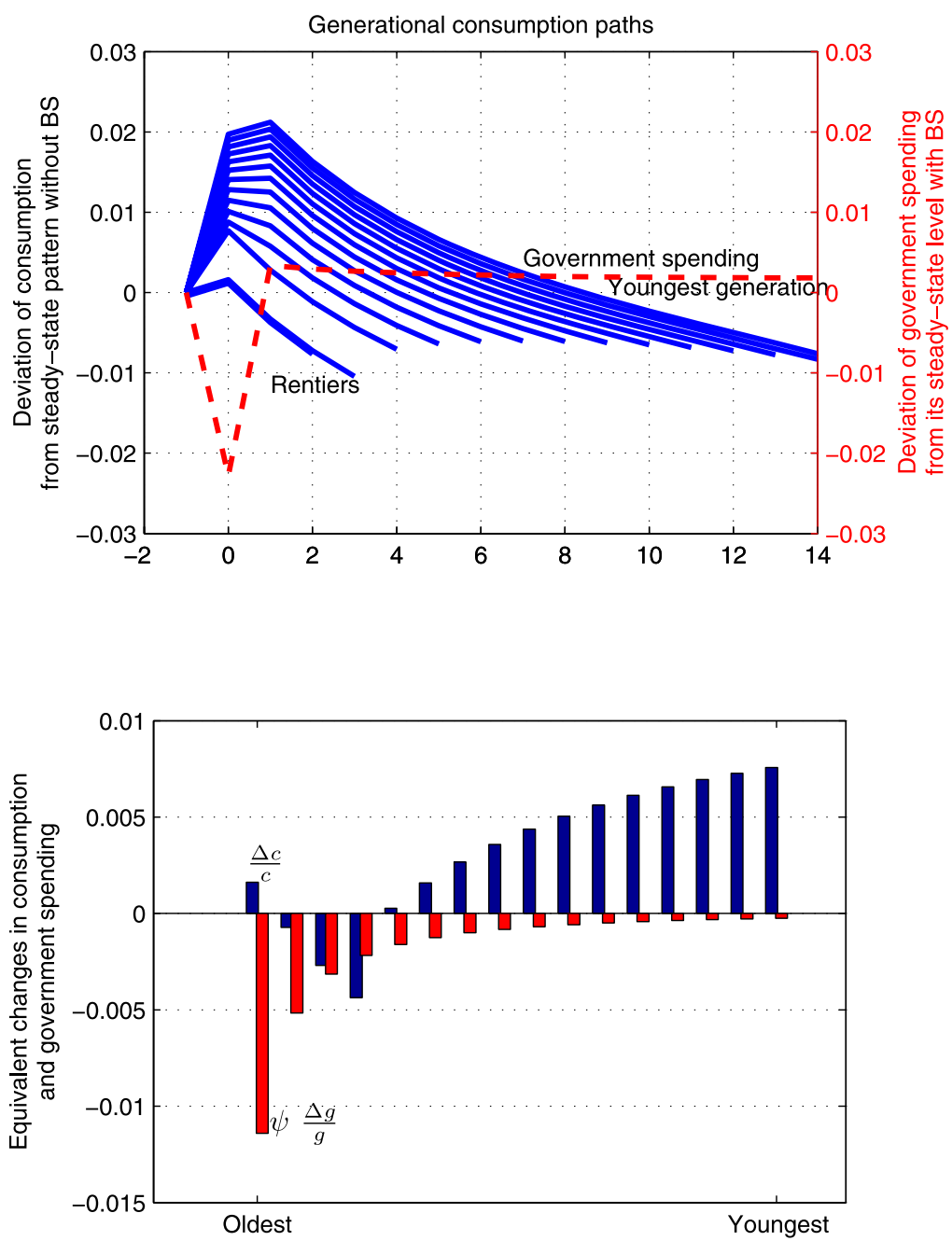

Fig. 7 Government spendings effects: pre-announced abolishment

\section{Appendix A: Consumers' maximization problem}

In this section we derive (3) from the consumers' maximization problem. We proceed by proving an expression for the value function. The optimal consumption rule will follow as a by-product. This is a standard dynamic programming exercise and it is quite likely that it could be found elsewhere.

Claim The value function of a generation $n$ individual with wealth $a_{n}$ can be written as

$$
V_{n}\left(a_{n}, R, \beta\right)=\frac{1-\beta^{n}}{1-\beta} \log a_{n}+T_{n}(\{R\}, \beta),
$$

where $T_{n}$ is a catch-all term for the exogenous variables. 

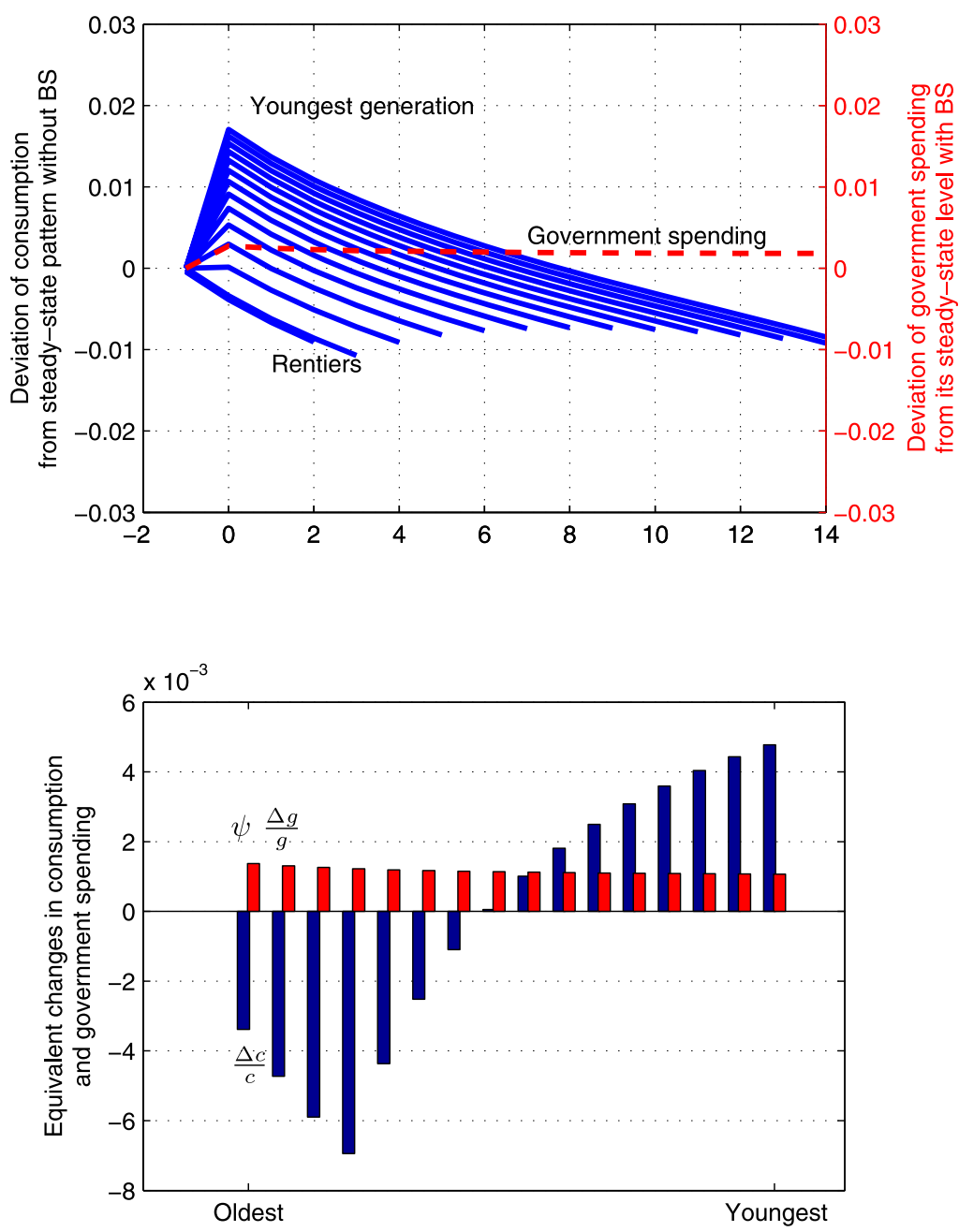

Fig. 8 Government spendings effects: surprise abolishment

Proof [By induction] In the last period of its lifecycle, a generation consumes all its wealth. It follows that $V_{0}\left(a_{0},\{R\}, \beta\right)=\log a_{0}$, so part (a) of the proposition obviously holds for $j=0$. Now assume it holds for period $j-1$ where $j$ is a positive integer. It follows that

$$
V_{j}\left(a_{j},\{R\}, \beta\right)=\max _{a_{j-1}}\left\{\log \left(a_{j}-R_{j}^{-1} a_{j-1}\right)+\frac{\beta-\beta^{j}}{1-\beta} \log a_{j-1}+\beta T_{j-1}(\{R\}, \beta)\right\} .
$$

The first-order condition for a maximum of the expression in braces implies that $a_{j-1}$ should be set to

$$
a_{j-1}=R_{j} \frac{\beta-\beta^{j}}{1-\beta^{j}} a_{j}
$$


It follows that the generation consumes

$$
c_{j}=\frac{1-\beta}{1-\beta^{j}} a_{j} .
$$

Substituting for $a_{j-1}$ in the value function and rearranging gives

$$
\begin{aligned}
V_{j}\left(a_{j},\{R\}, \beta\right)= & \log a_{j}+\log \frac{1-\beta}{1-\beta^{j}}+\frac{\beta-\beta^{j}}{1-\beta}\left(\log a_{j}+\log \left(R_{j} \frac{\beta-\beta^{j}}{1-\beta^{j}}\right)\right) \\
& +\beta T_{j-1}(\{R\}, \beta) \\
= & \frac{1-\beta^{j}}{1-\beta} \log a_{j}+T_{j}(\{R\}, \beta),
\end{aligned}
$$

which completes the inductive step and hence the proof. Since we just proved that the claim holds, the optimal consumption rule is given by (10).

\section{Appendix B: Solution algorithms}

\section{B.1 Steady states}

Solving for the steady states with and without banking secrecy is straightforward. From (9), we know the equilibrium tax rate under both regimes. The only state variable in the model is the capital stock. For a constant capital stock, the wage and interest rate, as well as consumption and savings for each generation are given by the formulas in Sect. 2.1. The equilibrium capital stock is that at which net savings over all generations is zero.

\section{B.2 Transition dynamics}

Solving for the transition dynamics between the two tax regimes is somewhat more complicated. Using the solutions for the steady states, we know the starting position of the economy (old steady state), as well as its new long-run equilibrium. At any point in time, household savings depend on the current state of the economy as well as the expected path for capital stock and the tax rate. The path for the tax rate depends on the evolution of the capital stock (which determines the tax base) as well as expected future tax rates. Using $\left\{\hat{k}_{t+j}\right\}_{j=1}^{\infty}$, $\left\{\hat{\tau}_{t+j}\right\}_{j=1}^{\infty}$, to denote the expected trajectories for the capital stock and the tax rates, a solution for the equilibrium transition dynamics is given when the realized paths equal their expectations.

We use the following procedure to arrive at the equilibrium path. Let $T$ be a period far ahead by which all adjustment dynamics should be completed. For period $T$ as well as all following periods we assume that all variables are at their new equilibrium values.

1. Assume an arbitrary path of the capital stock and tax rate for the transition.

2. Compute new series for both variables as follows:

(a) For given $\left\{\hat{k}_{t+j}\right\}_{j=1}^{T},\left\{\hat{\tau}_{t+j}\right\}_{j=1}^{T}$, and initial capital stock, compute aggregate period savings. Use this number as the capital stock for the period $t+1$. Then use the same procedure to compute the capital stock for $t+2$, etc. This yields a new estimate $\left\{\tilde{k}_{t+j}\right\}_{j=1}^{T}$ for the capital trajectory, as well as an estimated trajectory for the tax base $\left\{\tilde{b}_{t+j}\right\}_{j=1}^{T}$. 
(b) Collect the expected values in (8) into a variable $B$, so that, at time $t$,

$$
B=\sum_{j=1}^{\infty} \beta_{g}^{j} \bar{\tau}_{t+j} b_{t+j}+\frac{\beta}{1-\beta} \bar{g} .
$$

In the new equilibrium, $B$ is given by $B=\beta_{g} /\left(1-\beta_{g}\right) \bar{\tau}_{s s} b_{s s}$, where we use the subscript $s s$ to denote a steady state. Starting off in period $T$, we compute the expected period $T$ tax rate by $\hat{\tau}_{T}=1-B / \tilde{b}_{T}$. Given this value for period $T$, we compute $B$ for period $T-1$ as $B^{\prime}=\beta_{g} \hat{\tau}_{T} \hat{b}_{T}+\beta_{g} B$. Repeating the procedure until we are back in the period where the regime change took place yields an updated series of expected tax rates $\left\{\hat{\tau}_{t+j}\right\}_{j=1}^{T}$.

(c) Update the expected path for the capital stock by

$$
\left\{\hat{k}_{t+j}^{\prime}\right\}_{j=1}^{T}=\theta\left\{\tilde{k}_{t+j}\right\}_{j=1}^{T}+(1-\theta),\left\{\hat{k}_{t+j}\right\}_{j=1}^{T},
$$

where $\theta$ is a number in the range 0 to $1 ; \theta$ should be small in order to prevent too much oscillations of the expectations.

3. Check if for convergence by comparing $\left\{\hat{k}_{t+j}^{\prime}\right\}_{j=1}^{T}$ to $\left\{\hat{k}_{t+j}\right\}_{j=1}^{T}$. If not, go back to step 2 . 4. Verify that the economy has converged to the new steady state well before $T$. If not, increase $T$ and start over. If yes, a solution has been found.

\section{References}

Allingham, M. G., \& Sandmo, A. (1972). Income tax evasion: a theoretical analysis. Journal of Public Economics, 1, 323-338.

Bacchetta, P., \& Espinosa, M. (1995). Information sharing and tax competition among governments. Journal of International Economics, 39, 103-121.

Bacchetta, P., \& Espinosa, M. (2000). Exchange-of-information clauses in international tax treaties. International Tax and Public Finance, 7(3), 275-293.

Barro, R. J. (1973). The control of politicians: an economic model. Public Choice, 14, 19-41.

Boadway, R., \& Keen, M. (1998). Evasion and time consistency in the taxation of capital income. International Economic Review, 39(2), 461-476.

Brennan, G., \& Buchanan, J. A. (1980). The power to tax: Analytical foundations of a fiscal constitution. Cambridge: Cambridge University Press.

Chari, V. V., Kehoe, P. J., \& Prescott, E. C. (1989). Time consistency and policy. In R. Barro (Ed.), Modern business cycle theory. Cambridge: Harvard University Press.

Eggert, W., \& Kolmar, M. (2004). The taxation of financial capital under asymmetric information and the tax competition paradox. Scandinavian Journal of Economics, 106, 83-105.

Ferejohn, J. (1986). Incumbent performance and electoral control. Public Choice, 50.

Fischer, S. (1980). Dynamic inconsistency, cooperation and the benevolent dissembling government. Journal of Economic Dynamics and Control, 2(1), 93-107.

Huizinga, H., \& Nielsen, S. B. (2003). Withholding taxes or information exchange: the taxation of international interest flows. Journal of Public Economics, 87, 39-72.

Kollintzas, T., Philippopoulos, A., \& Vassilatos, V. (2000). Is tax policy coordination necessary? Mimeo, Athens University.

Marchand, M., Pestieau, P., \& Sato, M. (2003). Can partial fiscal coordination be welfare worsening? A model of tax competition. Journal of Urban Economics, 54, 451-458.

Niskanen, W. (1971). Bureaucracy and representative government. Chicago: Rand McNally.

Persson, T., Roland, G., \& Tabellini, G. (2000). Comparative politics and public finance. Journal of Political Economy, 108, 1121-1161.

Racheter, D. P., \& Wagner, R. E. (1999). Limiting Leviathan. Cheltenham/Northhampton: Edward Elgar. 
Rogers, C. A. (1987). Expenditure taxes, income taxes, and time-inconsistency. Journal of Public Economics, 32(2), 215-230.

Rogoff, K. (1990). Equilibrium political budget cycles. American Economic Review, 80, 21-36.

Schnellenbach, J. (2006). Tax morale and the taming of Leviathan. Constitutional Political Economy, 17, 115-130.

Stigler, G. J. (1971). The theory of economic regulation. Bell Journal of Economics, 2, 3-21.

Tullock, G. (1967). The welfare costs of tariffs, monopolies, and theft. Economic Inquiry, 5(3), 224-232. 